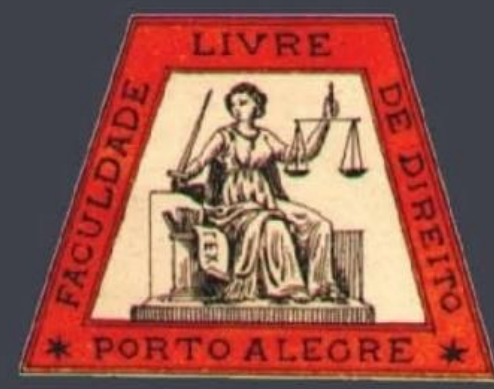

\title{
Direito indigenista nas constituições de Brasil e Canadá: um estudo comparado
}

\author{
Indigenous rights according to the Brazilian and Canadian \\ constitutions: a comparative study
}

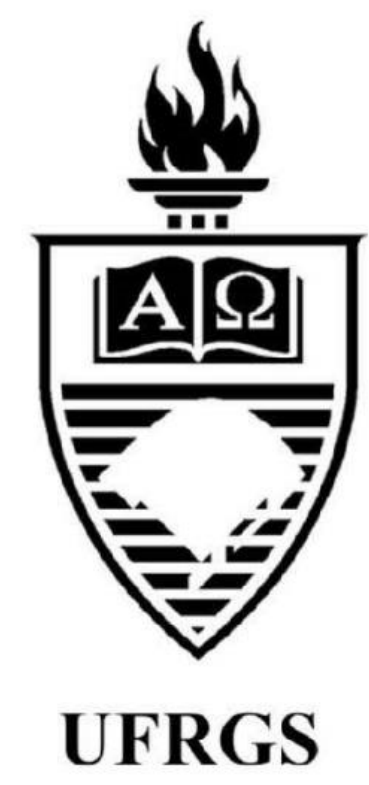

\author{
Heidi Michalski Ribeiro \\ Universidade Federal da Grande Dourados \\ João Nackle Urt \\ Universidade Federal da Grande Dourados
}




\title{
Direito indigenista nas constituições de Brasil e Canadá: um estudo comparado
}

\author{
Indigenous rights according to the Brazilian and Canadian constitutions: a comparative study
}

\author{
Heidi Michalski Ribeiro*
}

João Nackle Urt ${ }^{* *}$

\section{REFERÊNCIA}

RIBEIRO, Heidi Michalski; URT, João Nackle. Direito indigenista nas constituições de Brasil e Canadá: um estudo comparado. Revista da Faculdade de Direito da UFRGS, Porto Alegre, n. 36, vol. esp., p. 182-202, out. 2017.

\section{RESUMO}

Este artigo é resultado de uma análise comparada da história, das organizações sociais e dos ordenamentos jurídicos indigenistas de Brasil e Canadá. O estudo foi feito a partir de artigos científicos, livros e a legislação indigenista dos dois países. O objetivo deste estudo comparado é mostrar os resultados da colonização nas culturas e no modo de vida dos povos indígenas e como as Constituições e demais legislações abordaram a proteção aos índios. A chegada dos europeus nos dois países foi negativa aos nativos, trouxe doenças, exploração e dizimação. Os colonizadores desestruturaram as organizações sociais desses povos e tentaram lhes impor suas culturas e leis. Como fruto da resistência a assimilação e da luta pela autonomia, os indígenas conquistaram direitos fundamentais dentro de uma sociedade em que a maioria, tem preconceito contra as minorias. Desde a colonização até os dias atuais, este trabalho abordará como se deu a formação das políticas e legislações indigenistas de Brasil e Canadá.

\section{PALAVRAS-CHAVE}

Legislação Indigenista. Brasil. Canadá. Assimilação. Política indigenista.

\section{ABSTRACT}

This article is the result of a comparative analysis of the history, social organizations and indigenous legal systems of Canada and Brazil. The study had been done from scientific articles, books and the indigenous legislation of both countries. The aim of this comparative study is to show the results of colonization on cultures and life style of indigenous peoples and how the Constitutions and other legislations brought the Indians' protection. The arrival of Europeans in both countries was negative to the natives, brought diseases, exploitation and decimation. The settlers de-structured social organizations of these people and tried to impose them their cultures and laws. As a result of resistance to assimilation and the struggle for autonomy, indigenous conquered fundamental rights within a society where the majority is prejudiced against minorities. From colonization to the present day, this work will show how the indigenous legislation and policies formation in Brazil and Canada was.

\section{KEYWORDS}

Indigenous Legislation. Brazil. Canada. Assimilation. Indigenous Policy.

\section{SUMÁRIO}

Introdução. 1. Apreciação histórica dos direitos indígenas no Brasil. 2. Breve histórico dos direitos indígenas no Canadá. 3. Normas de direito indigenista nos ordenamentos jurídicos brasileiro e canadense atuais. Considerações finais. Referências.

Não compreendemos porque uma filha dos Kaingang precisa estudar leis escritas e aprender saberes que não são nossos. O que você precisa saber que os nossos velhos não podem lhe ensinar? O que se pode aprender de um povo que não respeita seus anciãos e abandona suas crianças? Para que irá um Kaingang estudar leis feitas por estranhos, leis que eles mesmos não cumprem? Não! Nunca compreenderemos que a lei seja não conhecida por todos, porque nossas leis não são

\footnotetext{
* Bacharel em Direito pela Universidade Federal da Grande Dourados. Membro do Observatório de Justiça Ecológica (OJE UFSC) e membro do Grupo de Pesquisa de Direito Ambiental na Sociedade de Risco (GPDA UFSC).

** Professor na Faculdade de Direito e Relações Internacionais da Universidade Federal da Grande Dourados (UFGD). Doutorado (2015) em Relações Internacionais pela Universidade de Brasília (UnB), Bacharel em Direito pela Universidade Federal de Mato Grosso do Sul (UFMS) (2001), possui Especialização (2006), Mestrado (2009).
} 
escritas, mas são cumpridas porque são sagradas." (frase de líderes do povo Kaiagang registradas em 1995 por Lúcia Kaiagang, advogada indígena, quando decidiu estudar direito).

\section{INTRODUÇÃO}

Apesar de Brasil e Canadá terem sido colônias e em ambos a população indígena já habitar os territórios quando da chegada dos europeus, o desenvolvimento dos dois países tomou rumos distintos, porém, foi similar o tratamento dado aos povos indígenas. Nos dois países, a conquista deu-se por meio do contínuo avanço sobre os territórios indígenas. $\mathrm{O}$ contato interétnico se deu durante um longo período e, apenas após aproximadamente cinco décadas é que os índios começaram a se organizar politicamente, buscando afirmar sua identidade e lutar por seus direitos (OLIVEIRA, 2013).

$\mathrm{Na}$ comparação dos aspectos das legislações que tratam dos direitos dos indígenas no Brasil e no Canadá, deve se levar em conta que conceitos similares podem ter diferentes significados, pois o contexto cultural e histórico dos dois países é diverso.

Tanto no Brasil, quanto no Canadá, a ideia era integrar os índios à sociedade não indígena, afim de que os nativos abrissem mão da própria cultura, para que pudessem ser "educados" pelos europeus. Aliás, os colonizadores acreditavam que os índios eram seres aculturados, sem religião ou crença, sem organização política ou social e que, ao integrar os nativos à sua sociedade, estariam prestando-lhes grande ajuda, pois integrando os índios, estariam lhes dando sentido à própria existência.

No cenário atual, o preconceito e o descaso com os povos tradicionais está apenas mais velado. Com o passar dos anos, diversas políticas foram adotadas pelos governos canadense $\mathrm{e}$ brasileiro, contudo, os retrocessos legislativos e sobretudo, a invisibilidade dos povos tradicionais é algo que está no cerne da sociedade.

\section{APRECIAÇÃO HISTÓRICA DOS DIREITOS INDÍGENAS NO BRASIL}

Historicamente, o direito não é efetivado às minorias. A sociedade e o Estado, oprimiam os povos indígenas de forma cruel e explícita e, quando questionados, alegavam que o Direito era igual para todos, que qualquer um poderia dele usufruir; mascarando a realidade e perpetuando às gerações futuras as injustiças criadas. Os primeiros povos que aqui habitavam eram donos de um vasto e rico território. A chegada dos colonizadores representou uma catástrofe na vida dos índios, que sofreram as mais diversas formas de violência. Os que sobreviveram à chegada dos portugueses foram isolados, deslocando-se para regiões mais remotas do Brasil.

Já nessa época, cada etnia tinha sua organização política e jurídica própria, mas o Império encarava todos como se fizessem parte de uma nação única, tratava-os como selvagens. Os povos indígenas foram divididos em duas grandes categorias, os "índios civilizados" e os "índios bravos" ou "tapuias", já antes do início das missões jesuíticas de 1551. Os "civilizados", pertencentes às tribos Tupiniquim e Temiminó, eram os que se submeteram à catequização e aos costumes portugueses, já os "bravos" eram os que apresentavam resistência à cultura dos brancos, que à época viviam principalmente no estado do Espírito Santo (LOSADA, 2001).

Pouco antes da promulgação da Primeira Constituição Brasileira, José Bonifácio de Andrada e Silva condenou a brutalidade com a 
qual os índios eram tratados, e ainda desferiu críticas indiretas à guerra promovida pelo príncipe regente Dom João. Apenar de suas ideias não estarem presentes na Constituição de 1824, Bonifácio deu o pontapé inicial no desenvolvimento político e nos debates sobre direito indígena no Império, através de sua obra “Apontamentos para a civilização dos índios bravos do Império do Brasil”, um projeto que os europeus classificavam como civilizacional, e cujo objetivo era que os índios bravos fossem educados e catequizados sem uso de violência. Entretanto, as ideias ditas protecionistas não atendiam em nada os interesses dos indígenas, pelo contrário, eram usadas como mecanismos de opressão:

O discurso da tutela legitimava as ações violentas e/ou autoritárias de imposição e transformação cultural sofridas pelas populações indígenas. [...] Embora tenha sido mais sutil e menos violenta que as demais, a tutela religiosa não perdeu seu caráter autoritário, realizando um trabalho de transmissão de outros valores na tentativa de anular a cultura autóctone (COLAÇO, 1999).

A Igreja teve grande participação na catequização dos índios, pois acreditava que ao apresentar Deus para esses povos, estaria lhes proporcionando evangelização e consequentemente, civilização, ou seja, estaria inserindo os índios na cultura europeia.

Ao analisar a obra de Bonifácio, COLAÇO (1999) nota que mesmo defendendo os indígenas com relação à violência a qual eram submetidos, Bonifácio não os considerava capazes de ter sua própria cultura e costumes, acreditava na tese integracionista. Para Bonifácio, a população indígena era, na melhor das hipóteses, uma espécie de página em branco, sem cultura, religião e vida social realmente apreciável, que poderia facilmente ser moldada segundo o padrão cultural e comportamental europeu (MOREIRA, 2009).

A Constituição de 1824 reconheceu os indígenas como sendo cidadãos brasileiros, conforme artigo $6^{\circ}$ da Carta: "São Cidadãos
Brazileiros: I - Os que no Brazil tiverem nascido, quer sejam ingenuos, ou libertos, ainda que o pai seja estrangeiro, uma vez que este não resida por serviço de sua Nação". Embora esse reconhecimento tenha sido importante no mundo jurídico, na prática nada mudou com relação ao tratamento disposto a esses povos.

Em 1850, com o advento da Lei 601 de 18/09/1850, a chamada Lei de Terras, iniciou-se um movimento de esbulho das propriedades rurais e o confisco das terras indígenas. A Lei assegurava o direito dos índios ao território, reconhecendo-os como primeiros donos da terra. Porem na mesma época, o próprio império criou uma regra dizendo as terras de aldeias que fossem abandonadas pelos índios seriam consideradas devolutas, ou seja, do Estado. Foram feitas então diversas manobras para que a maioria das terras indígenas fossem consideradas devolutas (ARAÚJO, 2006, p. 25).

Segundo BAINES (2003, p. 116), no nordeste brasileiro, o governo da época aboliu os aldeamentos e incorporou tais terras às comarcas e municípios que surgiam, ficando os indígenas sem um território próprio, perdendo suas identidades. "[...] é somente nas últimas décadas que muitas dessas populações estão voltando a se identificar como índios.”

Superada a monarquia, a fase políticorepublicana brasileira trouxe consigo uma nova Constituição, a Constituição da República dos Estados Unidos do Brasil, promulgada em 1891. A nova Constituição adotou a República Federativa como forma de governo, mas por ter seu texto muito parecido com o da Constituição norte-americana, faltou-lhe vinculação com o país e não obteve eficácia social. Essa desconexão deu-se pelo fato de a proclamação da República ter sido fruto de um golpe de Estado. A Constituição de 1891, portanto, careceu de legitimidade popular e durante sua vigência predominou apenas o poder presidencial. Tirando proveito disso, o governo ignorou as questões 
sociais, deixando os cidadãos brasileiros a mercê da intolerância dos poderosos.

Nesse sentido, BARRETO (2003, p. 38) afirma que de todas as Constituições brasileiras, a única que não reconheceu os direitos dos povos indígenas foi a de 1891. O texto constitucional por si só não muda a forma de agir e pensar da sociedade com relação aos índios; o preconceito e a rejeição existiram e existem.

Conforme artigo 64 da Constituição de 1891, todas as terras devolutas seriam devolvidas aos estados nos quais estavam localizadas. Em razão de muitas das terras indígenas terem sido consideradas devolutas, com a Lei de Terras de 1850, a Carta de 1891 agravou a situação territorial dos povos tradicionais. Ademais, a omissão da Constituição quanto aos direitos indígenas explica, segundo Araújo, o fato de o SPI - Serviço de Proteção ao Índio - não ter tipo à época, autonomia para reconhecer o território indígena:

Há que se dizer que a Constituição de 1891 não fazia qualquer menção aos índios ou aos seus direitos territoriais. Isto explica, por exemplo, porque o Serviço de Proteção aos Índios (SPI), que surgiu em 1910 , não tinha poderes para reconhecer as terras indígenas. O governo federal só demarcava terras indígenas após entendimentos com os governos estaduais e municipais. Tal situação continuou praticamente inalterada até os anos 60 , em que pesem as Constituições de 34, 37 e 46 terem trazido dispositivos reconhecendo a posse dos índios sobre as terras por eles ocupadas.

A prática de discutir as demarcações de terras indígenas com os governos de estados e de municípios agravou a política de confinamento anteriormente mencionada. As terras indígenas eram geralmente demarcadas em extensão diminuta, liberando-se o que estava em volta para que os governos pudessem titular. Como exemplo, pode-se uma vez mais mencionar o caso dos GuaraniKaiowá, no Mato Grosso do Sul, que foram alvo intenso da política de aldeamento do SPI, por meio da qual diversas comunidades foram sendo agrupadas em uma única aldeia, liberando-se as terras das demais para titulação a terceiros (ARAÚJO, 2006, p. 27).

Conclui-se que a Constituição de 1891 não fez qualquer menção à segurança dos índios, tampouco de suas terras, deixando-os desprotegidos em face de posseiros, grileiros e da ação dos governantes, confinados em aldeias cada vez menores, sem que fossem respeitadas as diferenças étnicas e culturais de cada povo.

Desde a entrada da Carta de 1891 em vigor, foram frequentes as crises e conflitos no país, devido à falta de compatibilidade do texto constitucional com a realidade brasileira, que levou pensadores e teóricos a propositura de uma reforma na Constituição. Em 1926 teve início a reforma, que traria, em 1934, uma nova Constituição.

Antes da vigência da Constituição de 1934, entrou em vigor a Lei $\mathrm{n}^{\circ}$. 3.071 de 1916, o antigo Código Civil. Os indígenas eram considerados incapazes e, portanto, necessitados de uma proteção especial. No artigo $6^{\circ}$, inciso III do antigo Código Civil, os índios, chamados de silvícolas, foram considerados relativamente incapazes dos atos da vida civil.

Apenas em 1962, com o advento da Lei 4.121, foi acrescentado um parágrafo único àquele artigo com a seguinte disposição: “Os silvícolas ficarão sujeitos ao regime tutelar, estabelecido em leis e regulamentos, o qual cessará à medida que se forem adaptando à civilização do País." (BARRETO, 2003, p. 40).

Aos cidadãos brasileiros, era assegurado, no art. 179 da Constituição de 1934, a não obrigatoriedade de fazer algo que não queiram senão em virtude de Lei; a liberdade de crença e de expressão; o direito de ir e vir; dentro outros. Todavia, a "proteção" trazida pelo artigo é tão falsa, quanto a noção de que os índios teriam os mesmos direitos e deveres que os portugueses.

O texto de MARÉS (1992) retrata a realidade dos índios à época imperial e republicana. Através de uma parábola, o autor relata que o homem passa a vida em frente à porta da Lei, aguardando para entrar, mas sempre há algo que o impede, até que o homem morre. No momento de sua morte, vê a porta sendo fechada 
e ao indagar o porquê do fechamento, lhe é respondido que a porta sempre esteve aberta e agora que não pode mais entrar, não há motivos para que continue aberta. Conclui:

\begin{abstract}
Assim os oprimidos quando chegam à porta da lei encontram um obstáculo, dificuldade, impedimento ou ameaça, mas o Estado e o Direito continuam afirmando que a porta está aberta, que a lei faz de todos os homens iguais, que as oportunidades, serviços e possibilidades de intervenção do Estado estão sempre presente para todos, de forma isonômica e cega (MARÉS, 1992, p. 146).
\end{abstract}

Nota-se que a questão dos direitos indígenas girou em grande parte em torno da terra, constitucionalmente falando, mas também, em torno de sua tutela, pois a teoria integracionista foi defendida desde a colonização e ainda não foi abolida totalmente.

$\mathrm{O}$ artigo $5^{\circ}$, inciso XIX, alínea "m", da Carta de 1934 diz que é de competência da União legislar a respeito da incorporação dos silvícolas à sociedade. E, no artigo 129, trata dos territórios indígenas: "será respeitada a posse de terras de silvícolas que nelas se achem permanentemente localizados, sendo-lhes, no entanto, vedado aliená-las".

Os índios estavam aos poucos se tornando cada vez mais dependentes da cultura dos brancos, tanto que muitos deles viraram mão-deobra barata em fazendas, para não ficar longe de seus territórios tradicionais (chamados pelos Guarani-Kaiowá do Mato Grosso do Sul de tekoha) (ARAÚJO, p. 27).

No ano de 1937, o Brasil se vê diante de uma nova Constituição, outorgada por um golpe de Estado que deu origem a um período conhecido como Estado Novo. O golpe deu-se pelo fato de a Constituição de 1934, bem como ocorreu com a de 1891, não estar em conexão com as necessidades do país; o que desencadeou diversas revoltas e movimentos que deixaram o Brasil em

\footnotetext{
${ }^{1}$ Art. 154 - Será respeitada aos silvícolas a posse das terras em que se achem localizados em caráter permanente, sendolhes, porém, vedada a alienação das mesmas.
}

situação vulnerável. Com relação aos indígenas, não trouxe quaisquer novidades ${ }^{1}$.

A Constituição de 1937 não chegou a viger, pois para isso, dependia de um plebiscito que nunca aconteceu. O presidente, a época Getúlio Vargas, quis dar nova roupagem a Constituição, adequando-a realidade brasileira. Através da Emenda Constitucional $n^{\circ} .9$, houve emendas na Constituição no ano de 1945, dentre elas a convocação de eleições ainda para aquele ano.

Com o cenário nacional e internacional conturbado, Getúlio Vargas foi deposto antes mesmo das eleições, assumindo o posto o Presidente do Supremo Tribunal Federal, José Linhares. Logo após, a Emenda Constitucional $n^{\circ}$. 13, o parlamento ganhou poderes para elaborar uma nova Constituição, que foi finalizada em 1946. A nova Constituição veio para pôr fim ao regime autoritário do Estado Novo. Foi vista como uma das melhores constituições brasileiras, por sua linha ideológica-libertária e por buscar medidas que melhor assegurassem os direitos individuais. (BASTOS, 1999, p. 142).

Para os indígenas não houveram mudanças efetivas. A Carta de 1946 trouxe um dispositivo a respeito dos territórios a eles pertencente, muito semelhante aos anteriores e, adotou novamente a política integracionista (art. $5^{\circ}, \mathrm{XV}$, “r"). Com a crescente expansão das fronteiras, os indígenas foram sendo expulsos de seus territórios originais e, para eles, sagrados. Exatamente como nas Constituições anteriores, havia um dispositivo legal, que era totalmente desrespeitado ${ }^{2}$.

A principal exceção desse descaso com os territórios indígenas foi o surgimento do Parque Nacional do Xingu, em 1961. A criação do parque mudou a forma com a qual as terras indígenas eram demarcadas no Brasil. Participaram da luta para criação do parque os irmãos Villas-Boas e Darcy Ribeiro e o objetivo era preservar o modo

2 Art. 216 - Será respeitada aos silvícolas a posse das terras onde se achem permanentemente localizados, com a condição de não a transferirem. 
de vida dos indígenas da região do Xingu e o meio ambiente. A criação do parque não só trouxe uma mudança positiva, como também um novo paradigma, que viria a ser discutido no decorrer dos anos 80:

[...] o conceito de terra indígena passaria a incorporar outros elementos visando à reprodução sociocultural dos povos indígenas. Naquele momento, tratava-se, como diziam os próprios defensores da criação do Parque, de preservar um pedaço do "Brasil prístino", onde os índios ainda mantinham as suas culturas de forma harmoniosa com a natureza e longe da influência do chamado mundo civilizado (ARAÚJO, p. 28).

A criação do Parque, de certa forma, trouxe um novo olhar para a ideia de que os índios deveriam esquecer sua própria cultura, abandonar suas raízes; ou seja, extinguir sua condição de cidadão indígena. Embora a política e a Constituição pregassem que os índios deveriam ser assimilados pela sociedade e abandonar sua condição de indígena, a criação do parque foi pensada justamente para fazer oposição a essa ideia, o que representou um grande avanço para preservação da identidade desses povos (ARAÚJO, p. 29).

Em 1967 entrou em vigência uma nova Constituição, que repetiu o discurso integracionista. Em seu artigo $4^{\circ}$, inciso IV, a nova Carta passou as terras ocupadas pelos índios para domínio da União, já no artigo 186, a Carta reconhecia o direito dos indígenas sobre a terra, bem como sobre os recursos naturais nela existentes $^{3}$.

No mesmo ano de criação da nova Carta, a Lei $\mathrm{n}^{\circ}$. 5.371, de 5 de dezembro de 1967, autorizou a criação da Fundação Nacional do Índio (FUNAI), o que automaticamente extinguiu o Serviço de Proteção ao Índio e o Conselho

\footnotetext{
${ }^{3}$ Art. 186 - É assegurada aos silvícolas a posse permanente das terras que habitam e reconhecido o seu direito ao usufruto exclusivo dos recursos naturais e de todas as utilidades nelas existentes.
}

Nacional de Proteção aos Índios; integrou para si os patrimônios deixados por esses órgãos, bem como incorporou o Parque Nacional do Xingu. Dentre as atribuições da FUNAI estão: o respeito ao índio e às suas instituições tribais; bem como a preservação da cultura indígena no seu contato com a cultura dos não índios.

A Emenda Constitucional $\mathrm{n}^{\circ} 1$ de 1969 trouxe profundas mudanças para a Constituição de 1967, mudando-a de tal forma, que muitos disseram tratar-se de uma nova Constituição, a Carta de 1969. A maior inovação constituiu em incluir no texto constitucional um dispositivo que declarava as terras indígenas como parte do patrimônio da União, o que afastava, pelo menos no plano formal, o processo de esbulho que vinha sendo praticado pelos estados, além de centralizar a questão indígena na esfera federal (ARAÚJO, 2006, p. 30).

Outra mudança importante trazida pela Emenda foi o reconhecimento do direito dos índios de usufruir plenamente dos bens e riquezas naturais existentes em suas terras, dando-lhes a possibilidade de proteger a terra até no âmbito jurídico; e ainda, a mais importante e significativa mudança: eram nulos e extintos quaisquer atos que incidissem sobre a posse das terras indígenas. Foi um grande passo na garantia do direito à terra, o que obviamente gerou muita polêmica na época (ARAÚJO, 2006, p.30).

No ano de 1973, entrou em vigência a Lei $\mathrm{n}^{\mathrm{o}}$. 6001, o Estatuto do Índio. Foi essa Lei que trouxe a definição de índio e de comunidade indígena, feita com base em critérios genealógicos, culturais e de pertença étnica (BARRETO, 2009, p. 33). Já em seu artigo primeiro, o Estatuto mostra que a sociedade brasileira ainda acreditava na teoria integracionista ${ }^{4}$.

\footnotetext{
${ }^{4}$ Art. $1^{\text {o }}$. Esta Lei regula a situação jurídica dos índios ou silvícolas e das comunidades indígenas, com o propósito de preservar a sua cultura, e integrá-los, progressiva e harmoniosamente, a comunhão nacional.
} 
A Constituição de 1988 trouxe uma das principais mudanças com relação aos povos tradicionais: o reconhecimento de sua identidade e do princípio da autodeterminação. Desde a colonização, a ideia que se fazia dos indígenas era de que estavam fadados a perder suas identidades e sua cultura ao longo do tempo. Tanto é verdade que várias as políticas governamentais e os artigos das Constituições anteriores deixavam claro que a melhor medida a ser tomada quanto aos índios era a catequização, a educação e inserção na sociedade. Aos poucos a ideia integracionista é abandonada e o direito a identidade é reconhecido.

\section{BREVE HISTÓRICO DOS DIREITOS INDÍGENAS NO CANADÁ}

No início da colonização América do Norte pelos europeus, os habitantes nativos não possuíam um status legal, tampouco direitos, no que se refere aos direitos internacionais da época. Os povos aborígenes não eram reconhecidos como entidades internacionais, devido a diversos fatores, tais quais o modo de vida, uma estrutura política muito difusa e crenças religiosas diferentes à dos europeus. E, ainda, esses povos não tinham nenhum direito às terras que ocupavam, pois o eurocentrismo tornava os colonizadores incapazes de reconhecer a soberania desses povos.

As primeiras expedições dos europeus para o Canadá em meados de 1480, quando o explorador inglês John Cabot começou expedições para cruzar o atlântico. Em 1497, ele desembarcou em Newfoundland. À época, os interesses estavam voltados mais para pesca do que para colonização propriamente dita. O comércio de peles de animais foi o que deu início à relação entre ingleses e aborígenes. Num primeiro momento, os índios trocavam as peles

\footnotetext{
5 "Before long a population arising from these marriages between indigenous people and French traders in the prarie
}

por mercadorias como ferramentas e armas. Percebendo que aquele comércio poderia ser lucrativo na Europa, ingleses e franceses passaram a explorá-lo. Na América do Norte, o comércio de peles contribuiu significativamente para o desenvolvimento dos impérios britânico e francês (PERRY, 2001). Segundo Perry, foram os franceses que na verdade exploraram o que mais tarde seria o baixo Canadá. Em 1534, o francês Jacques Cartier velejou pelo rio Lawrence e, no percurso, encontrou vilas de povos aborígenes, próximos a onde hoje fica Quebec.

O país foi ocupado majoritariamente por britânicos, e por franceses na região de Quebec. A ocupação do Canadá deu-se pela importação de famílias britânicas para o país, tendo ocorrido dessa forma, um maior equilíbrio entre a população masculina e feminina. A mestiçagem deu-se em um grupo menor, que no Canadá é conhecido como Métis (filhos de pai europeu e mãe indígena). "Há muito tempo, a população que surgia dos casamentos entre povos indígenas e mercadores franceses nas províncias das savanas crescia para tornar-se uma distinta comunidade conhecida como Métis" (PERRY, 2001, p. 132) (tradução livre) $^{5}$.

O censo usado para contagem da população indígena é o critério da auto-determinação, de maneira que a população aborígene soma 1,2 milhões, representando $4 \%$ da população canadense. Segundo BAINES, há três categorias para identificar os aborígenes: Índios, Métis e Inuit. A realidade social desses povos é bastante distinta, pois os três grupos são formados por aborígenes que se auto-identificam de maneiras diversas:

\footnotetext{
As categorias adotadas pelo governo para definir índios refletiam a necessidade de especificar quais pessoas tinham o direito de morar na reserva. Assim, criaram-se duas categorias de índios (...) "Status Indians" refere-se a aqueles que têm status jurídico sob o Indian Act (...) determinado por descendência
}

provinces had grown to become a distinct community known as Métis." 
patrilinear, a partir do registro governamental de 1876. (WEAVER, 1984, p. 188)

Num primeiro momento, os colonizadores franceses encorajavam a miscigenação. "Nossos jovens homens se casaram com suas filhas e vocês poderão ser um povo (DIACKSON, 1992, p. 167) (tradução livre) ${ }^{6} "$. Contudo, prevaleceu uma noção de assimilação baseada na cultura, ou seja, os colonizadores acreditavam que os aborígenes eram indivíduos aculturados, de maneira que a integração ocorreria de forma natural.

Não é por acaso que os depoimentos políticos atuais de lideranças aborígenes são permeados por acusações de racismo dirigidas ao governo, além de tentativas de reivindicar direitos originários, estratégia adotada no Canadá na autorepresentação dos povos indígenas como "Primeiras Nações" (BAINES, 2003, p. 118).

Nas terras colonizadas por britânicos, o common law pregava a extensão de seu sistema legal aos povos autóctones, já nas terras colonizadas pelos ibéricos, o objetivo principal era dominar os nativos e usar a força de trabalho para produzir lucro para Coroa. A política adotada foi a do reconhecimento dos direitos indígenas sobre suas terras ancestrais, através do Royal Proclamation, de 1763, cujo principal objetivo era organizar a nascente conquista britânica e estabilizar a relação com os nativos, e, para tanto, a Coroa entendeu que para manter uma relação cortês com os aborígenes, era necessário demonstrar respeito com relação à posse destes sobre suas terras. A Coroa então reservou algumas áreas para os índios, áreas essas, logicamente, fora dos limites das novas colônias de Quebec, bem como do leste da Flórida (SLATTERY, 1996).

Ocorre que, o Royal Proclamation também deu ao rei o direito de apropriar-se das terras indígenas e estabelecer acordos de rendição dos índios com europeus. Com isso, ao final do século

\footnotetext{
6 "Our young men will marry your daughters, and we shall be one people."
}

XVIII e início do XIX, os tratados de rendição, dos quais eram signatários índios e europeus, confinaram os nativos em porções de terras cada vez menores. O Royal Proclamation tem poder constitucional no país e nunca foi revogado (SCHOULS, 2002).

Em 1876 foi promulgado o Indian Act pelo parlamento canadense através a Sessão 91 da Constituição de 1867, que forneceu ao governo federal canadense exclusividade em legislar em relação aos índios e suas terras. O Indian Act define quem é indígena e estipula quais são os direitos desses povos na sociedade.

Conforme o Indian Act, as terras pertenciam a Coroa, que as controlavam em nome dos aborígenes através da figura do Minister of Indian Affairs, um órgão do governo que atuava nas causas indigenistas. Foram criadas reservas indígenas e a ideia era que eles fossem assimilados e civilizados de acordo com as premissas europeias e, enquanto isso não ocorresse, viveriam sob a tutela do Estado; ele era o aparato jurídico que mantinha os índios em posição de dependência. As Cortes superiores restringiram o direito à pesca, a caça, bem como o direito a atravessar os limites das reservas (HARRIS, 2001).

Os tratados tinham um significado muito forte para os povos aborígenes. "Os tratados representavam o mais importante instrumento legal do "homem branco", pois dava a eles o reconhecimento aos olhos do mundo como colonizadores originários no país" (JOHNSON, 2007) (tradução livre) ${ }^{7}$.

Para os nativos canadenses, o mecanismo mais importante de perpetuação de seus valores era a palavra, acordos orais valiam como letra de lei nas culturas indígenas canadenses, de maneira que se sentiram enganados pelos tratados escritos,

\footnotetext{
7 Treaties represent the most important "white men" legal instrument giving them recognition in the eyes of the world as original settlers in the country.
} 
com sua linguagem ambígua que nada os favorecia (SUTTON, 2011).

Segundo Slattery (1996), a primeira Constituição Canadense teve como base a legislação britânica. A Carta Canadense era constituída de estatutos do Parlamento Imperial, fundados em princípios constitucionais ingleses. Esses estatutos incluíam o Constitution Act, de 1867 e o Canadian Charter of Rights and Freedoms, feitos pelo Parlamento britânico a pedido do Canadá.

Entre os anos de 1871 e 1923, a criação de reservas indígenas através de tratados resultou numa distinção entre os índios. Os Status Indians eram os índios reconhecidos pelo governo e os non-status Indians eram os Métis e os não reconhecidos pelo governo como índios. As primeiras organizações políticas indígenas datam a partir de 1890 (SAWCHUK, 1993).

A expectativa do governo é que os povos fossem assimilados, acreditava-se que eles abririam mão de sua cultura, crenças, língua e viveriam como os colonizadores britânicos. Os europeus acreditavam que, para que os aborígenes não oferecessem mais resistência à colonização, as crianças deveriam ser educadas conforme as escolas europeias. Após 1920, a presença dos aborígenes era obrigatória nas escolas canadenses, os pais eram ameaçados de prisão caso não mandassem os filhos. As escolas eram extremamente assimilacionistas e os menores sofriam abusos psicológicos, físicos e sexuais (OLIVEIRA, 2013, p. 7).

Em 1961, ocorreu à formação do National Indian Council, órgão criado pelos próprios aborígenes. Um Conselho cujos objetivos eram promover a cultura indígena e acompanhar o desenvolvimento dos povos. Através do Conselho foi possível averiguar diversas irregularidades, desde a assinatura dos primeiros tratados até documentos que comprovavam a ilegitimidade de algumas transações de terras feitas de índios aos não-índios.
A reação dos aborígenes fez levantar a seguinte questão: os povos nativos devem ser integrados à sociedade? Deve o status de nação autônoma ser respeitado ou ignorado? (BAINES, 2003). O que prevaleceu no Canadá foi a ideia de que os aborígenes poderiam manifestar-se livremente como sociedades diferentes da sociedade não-indígena, desde que permanecessem como bons servidores à Coroa britânica, obedecendo as interpretações que a Coroa desse aos tratados.

O governo de Trudeau propôs a White Paper, em 1969. Um instrumento que promoveria uma reforma dos direitos dos aborígenes. O governo percebeu que isolar os índios em reservas só tornou-os mais independentes e resistentes à assimilação. Através do White Paper o governo se auto acusou de promover barreiras entre os aborígenes e a sociedade canadense, causando a apatia e pobreza dos nativos e que, para contornar tal situação, toda legislação especial construída durante anos a esses povos deveria ser extinta, para que se pudesse alcançar igualdade (SCHOULS, 2012, p. 19).

Em resposta ao White Paper, os aborígenes criaram o Red Paper, documento no qual apontavam o Indian Act como um símbolo de discriminação e racismo. Os intelectuais imaginavam as reservas como guetos, nos quais os aborígenes eram forçados a viver e a noção de segregação disseminada à época, estava intimamente ligada às reservas (FIDLER, 1970).

A ligação dos povos aborígenes com a terra, suas políticas e sistemas legais próprios, dentre outros fatores, foram decisivos para que esses povos fossem vistos de maneira diferente, pois passaram a reivindicar seus direitos de forma mais efetiva. Para gerir essas reivindicações, o governo canadense criou, em 1974, o Office of Native Claims. Esse órgão era responsável por receber diversos pedidos feitos pelos índios, principalmente os relativos a terra. Com o passar dos anos, em virtude das inúmeras reivindicações, 
houve a formação e o aumento de reservas e a criação de direitos especiais para o uso da terra (JOHNSON, 2007).

O Constitution Act de 1982 foi inicialmente aprovado para fornecer poderes legislativos ao parlamento canadense, pensando em remover a influência do parlamento britânico no país. Para as nações aborígenes, o Act tinha por objetivo restaurar a importância dos tratados e colocá-los no mesmo patamar de importância que os não aborígenes perante o governo.

Como impulso para seus movimentos, os povos aborígenes declararam que o sistema legal canadense não lhes trouxe proteção, ao contrário, tirou a ordem que havia entre eles e implantou outra completamente inadequada. Uma das conquistas desses povos foi a restauração dos direitos mais importantes presentes nos tratados, como por exemplo, o reconhecimento ao direito sobre a terra (JOHNSON, 2007).

Outra conquista foi o reconhecimento de todos os grupos indígenas como uma categoria diferente de cidadãos, os quais devem ter direitos especiais e diferenciados garantidos. Tal reconhecimento está contido na Section 35 do Constituion Act. A partir de então o governo canadense percebeu a importância de assinar tratados com os aborígenes, povos excluídos por tanto tempo.

Uma série de tratados foram assinados e como resultado de um deles, houve a criação da província de Nunavut (SUTTON, 2011). “(...) Nunavut, uma nova província canadense, foi criada no leste parte dos territórios noroestes. A maioria da população que vive na nova província é Inuit, onde este povo lidera o governo" (tradução livre) $^{8}$.

Depreende-se, desta forma que, ao longo dos anos de colonização, os povos aborígenes

\footnotetext{
${ }^{8}$ (...) Nunavut, a new Canadian province, was created in the eastern part of the current Northwest Territories. Most of the population living in the new province is Inuit, where this group heads the government.
}

foram conquistando espaço entre os colonizadores, bem como reafirmando seus direitos apesar de toda opressão sofrida. Vê-se ainda que, apesar de isolados em reservas e oprimidos pela cultura europeia, a resistência oferecida por esses povos e a organizações políticas fez com que os aborígenes canadenses obtivessem um maior reconhecimento perante a sociedade.

\section{NORMAS DE DIREITO INDIGENISTA NOS ORDENAMENTOS JURÍDICOS BRASILEIRO E CANADENSE ATUAIS.}

O censo de 2010 realizado pelo Instituto Brasileiro de Geografia e Estatística, o IBGE, apurou a população 896,6 mil indígenas no Brasil ${ }^{9}$. Já a população indígena canadense atual corresponde a $4 \%$ da população total, aproximadamente 1,5 milhões de habitantes, de acordo com censo realizado em $2011^{10}$.

Tanto no Brasil, quanto no Canadá, a maior parte da população indígena vive nas áreas de menor densidade populacional, sendo no primeiro, a região centro-oeste e amazônica e no segundo, a região norte do país, pois com o avanço da colonização, foram sendo isoladas em espaços cada vez menores, perdendo seus direitos sobre a terra (BAINES, 119). E é esse direito, o de ocupar suas terras, que se tornou um dos propulsores aos mais diversos movimentos indigenista no Brasil e no Canadá. Foram esses movimentos que iniciaram a organização política dos índios para reivindicação de direitos e com isso, a reformulação dos direitos nos tratados e Constituições.

Ao contrário do Brasil, no Canadá os povos aborígenes não foram privados de suas terras logo após a chegada dos colonizadores. No início, os

\footnotetext{
${ }^{9}$ Disponível em: <http://indigenas.ibge.gov.br/>.

${ }^{10}$ Disponível em: <www.canadainternacional.gc.ca $>$.
} 
franceses deixaram os aborígenes canadenses na posse de suas terras para manter um bom relacionamento (PERRY, 2001, p. 126). Nos dois países, os franceses fizeram a política da "boa vizinhança". Historiadores afirmam que a presença francesa trouxe uma imagem positiva dos colonizadores, quando comparados com portugueses e britânicos. Afirmam que os franceses conquistaram a simpatia dos povos indígenas por terem estabelecido com eles relações mais estreitas e igualitárias e ainda, que não há relatos de escravização dos nativos por parte dos franceses (MOISES, 1996):

A imagem do colonizador fraternal permanece, contudo, colada aos franceses, nos dois extremos da América. Mestres da diplomacia indígena, profundos conhecedores das línguas e culturas ameríndias, capazes de compreendê-las e respeitálas, e não-praticantes da escravização dos índios, deixaram boas lembranças. Se o comércio é parte importante da explicação desse fenômeno, ao que se poderia acrescentar o fato de os franceses serem o colonizador que deixou de ser, o que certamente favorece sua mitificação, em contraposição aos "maus" colonizadores que ficaram (portugueses e ingleses), o "mistério" persiste. Se são os próprios franceses os grandes propagandistas do mito, o fato é que seus concorrentes confirmavam-no, e a historiografia recuperou-o. Para praticar o mesmo tipo de comércio que outros europeus na América, os franceses utilizavam técnicas próprias e que teriam até mesmo sido copiadas por comerciantes de outras nacionalidades, dado seu evidente sucesso junto às populações indígenas (MOISES, 1996, p. 7).

Contudo, mesmo mantendo um bom relacionamento com povos indígenas, o objetivo dos franceses era o mesmo dos portugueses e dos britânicos: obter lucro com a colonização. A postura dos franceses na verdade foi uma tática para atingir esse objetivo de forma menos conflituosa.

Após seis constituições, foi promulgada em 1988, a Constituição a vigente no Brasil. Conhecida como "Constituição Cidadã", a Carta foi promulgada no governo de José Sarney e tem como preceito fundamental dar maior liberdade ao cidadão brasileiro. Ao todo são onze artigos que fazem menção à situação jurídica das populações indígenas (KAYSER, 2010).

A Constituição de 1988 não repetiu o que previam as Cartas anteriores, ou seja, retirou do texto constitucional a incorporação dos índios à comunhão nacional, incorporação. Segundo Ricardo (1996), após a Constituição de 1988, surgiram várias organizações indígenas de caráter étnico. Assim como no Canadá, onde a política indigenista era "autônoma e permanente, é uma realidade fundamental local, faccionada $\mathrm{e}$ descentralizada (RICARDO, 1996, p. 91)".

A Carta traz em seu artigo 231, caput: São reconhecidos aos índios sua organização social, costumes, línguas, crenças e tradições, e os direitos originários sobre as terras que tradicionalmente ocupam, competindo à União demarcá-las, proteger e fazer respeitar todos os seus bens. Tal artigo é complementado pelo artigo 210 , parágrafo $2^{\circ}$, que assegura às comunidades indígenas o uso de sua própria língua no sistema educacional. O artigo 215 , parágrafo $1^{\circ}$ prevê que cabe a União proteger as manifestações das culturas indígenas. "A Constituição de 1988, em comparação às suas precedentes, representa a alteração da terminologia que se refere aos "aos índios", às "comunidades" e aos "grupos indígenas", ao invés da designação de "silvícolas" empregada nas constituições anteriores". (KAYSER, 2010, p. 207).

Segundo Baines, após a Constituição Federal de 1988, as organizações indígenas passaram a ser consideradas como sujeito de ação jurídica. Sobre o Canadá o autor leciona:

No Canadá houve tentativas de constituicionalizar os direitos indígenas e o reconhecimento a autonomia política. A criação de reservas indígenas através dos Tratados entre 1871 e 1923, processo que acompanhou a aceleração da colonização do continente, resultou numa distinção entre status Indians (aqueles incorporados nos Tratados, e que tinham o status de índios reconhecido pelo governo) e non-status Indians (aqueles não incorporados nos Tratados, os Métis, e os nativos emancipados). (...) Porém, foi somente em 1982 que a Constition Act 
incluiu os Métis, antes numa situação ambígua (BAINES, p. 121).

No ano anterior à promulgação da Constituição de 1988, o governo brasileiro tentou introduzir na legislação, através do Decreto 94.946 de 1987, uma distinção entre "índios não aculturados" que viveriam em áreas indígenas e os "índios aculturados", que viveriam em colônias indígenas (OLIVEIRA, 1996). Segundo Oliveira, essa norma indica ações que visam lucro nas áreas indígenas, baseado pela possível aculturação dos índios.

O Constitution Act de 1982, assim como a Constituição Federal brasileira de 1988, foram os ordenamentos que trouxeram direitos específicos aos povos aborígenes do Canadá e os povos indígenas do Brasil. Se esses direitos são ou não respeitados e defendidos por todos não há como se afirmar com certeza, mas estão positivados na Constituição, tanto brasileira, quanto canadense.

A Constituição canadense é dividida em sessões. Dentre todas, três delas merecem maior destaque, pois elencam os direitos aos índios de forma expressa. Primeiramente, a Section 35, intitulada "Rights of Aboriginal Peoples of Canada" 11 . Esta sessão reconhece os tratados e direitos dos aborígenes já existentes e os reafirma. Para julgar qualquer caso envolvendo aborígenes, os juízes devem levar em consideração os tratados existentes. Segundo Mcneil, os aborígenes acreditavam que a Section 35 lhes asseguraria direitos. "Além disso, os povos aborígenes tem sido levados a acreditar que a sessão 35(1) realmente dá proteção à seus direitos; se esta não foi a intenção, os políticos desse país cinicamente distorceram a situação" (MCNEIL, p. 256) (tradução livre) $)^{12}$.

\footnotetext{
${ }^{11}$ Direitos dos povos aborígenes do Canadá - tradução livre

${ }^{12}$ (...) Furthermore, the aboriginal peoples have been led to believe that section 35(1) does provide such protection for their rights; if this was not the intention, the politicians of this country have cynically misrepresented the situation.
}

Em suma, a sessão 35(1) prevê que os direitos conquistados ou existentes em tratados não podem ser extintos por qualquer outra legislação. A segunda parte da sessão 35, a Section 35(2) define que são povos aborígenes do Canadá, quais sejam os índios, os Inuit e os Métis (que foram incluídos após anos de esquecimento) (MCNEIL, p. 260).

No Brasil, a Constituição de 88 trata da questão indígena no Capítulo VIII, que conta dois artigos, o 231 e o 232 . O artigo 231 contem seis parágrafos, que versam sobre a questão das terras indígenas, tema polêmico no cenário nacional. Além dos artigos dispostos na Constituição e da Lei 6001 de 1973, temos hoje as seguintes convenções que vigoram no Brasil: o Sistema Interamericano de Proteção aos Direitos Humanos e a Convenção 169 da Organização Internacional do Trabalho, bem como o artigo $27^{13}$ do Pacto Internacional sobre os direitos políticos e civis (KAYSER, 2010, p. 173).

Nas regiões do Brasil em que a população indígena é considerável, a luta pelas terras faz com que esse preconceito aumente e a sociedade, cada vez mais exclua e oprima os índios. De acordo com a Constituição Federal, as terras ocupadas pelos índios são de propriedade da União. Segundo Bastos, são consideradas terras indígenas às que tenham as seguintes características:

[...] a) serem ocupadas pelos índios sob forma de ocupação, é dizer, as terras permanentemente habitadas por índios; b) as utilizadas para as suas atividades produtivas; c) as imprescindíveis à preservação dos recursos ambientais necessários a seu bem-estar e; d) as necessárias à sua reprodução física e cultural, segundo seus usos, costumes e tradições (BASTOS, 1999).

\footnotetext{
${ }^{13}$ Artigo 27. Nos Estados em que haja minorias étnicas, religiosas ou linguísticas, as pessoas pertencentes a essas minorias não poderão ser privadas do direito de ter, conjuntamente com outros membros de seu grupo, sua própria vida cultural, de professar e praticar sua própria religião e usar sua própria língua
} 
Na prática, não é o que acontece. Muito sangue indígena já foi e continua sendo derramado, em virtude da disputa por terras, especialmente no estado de Mato Grosso do Sul. Os territórios originários indígenas no Brasil são hoje ocupados por grandes fazendas e a demora do governo em demarcar as terras gera cada vez mais conflitos. Conclui-se que, no Brasil, a maior causa de conflito é a questão das terras. No Canadá, a situação não é tão grave quanto no Brasil, mas os conflitos pelos territórios tradicionais existem.

\begin{abstract}
Criou-se em dezembro de 1991 um território esquimó (ou Inuit) de cerca de 2 milhões de $\mathrm{km}^{2}$, chamado Nunavut, ("terra da gente, na língua esquimó), equivalente aos estados de Amazonas, Amapá, Acre e Roraima juntos, com 17.500 mil habitantes. Em um sexto do território, os Inuit tem controle absoluto das riquezas naturais e do autogoverno. Nos restante, recebem 5\% sobre a exploração de riquezas naturais. Além disso, o governo do Canadá lhes paga US\$ 1 bilhão em 14 anos. Em troca, os Inuit abriram mão de todas as ações legais movidas por motivos territoriais ${ }^{14}$.
\end{abstract}

O Constitutional Act traz diversas provisões sobre as terras e reservas indígenas. As reivindicações no Canadá, diferentemente do Brasil, não tem foco principal na questão de terras, mas sim para a relação política com o Estado. A luta dos aborígenes tem foco no reconhecimento e na autonomia. A intenção dos nativos é livrar-se da dominação colonial que persiste até os dias de hoje.

O conteúdo da constituição canadense é mais detalhado que os artigos trazidos na Constituição brasileira. Claro que no Brasil ainda há as outras legislações, porém a legislação canadense parece ter maior amplitude em que pese à defesa de direitos. Todavia, é difícil afirmar em qual dos dois os direitos dos povos indígenas são mais garantidos, pois o preconceito existe em ambos.
Os povos aborígenes canadenses aparentemente tiveram mais conquistas políticas que os indígenas brasileiros. Isso porque sua organização política dos aborígenes se deu muito antes que no Brasil. Os nativos do Canadá começaram a organizar-se politicamente, criando movimentos para pressionar o governo muito cedo. Algumas organizações políticas atuais datam de meados da década de 30. Enquanto no Brasil, a maior luta ainda é pelo direito a terra, no Canadá a luta é pelo reconhecimento às diferenças entre a sociedade não indígena e os aborígenes (BAINES, p. 121).

A Constituição indígena permitiu uma reinterpretação dos direitos indígenas pelos tribunais, agora não mais vistos como direitos consuetudinários, mas sim, direitos constitucionais. Contudo, não se pode afirmar que o Canadá está à frente do Brasil no que tange a garantia de direitos aos índios. Ao contrário, segundo Asch (1999), a ideologia do estado canadense ainda não rompeu com a ideia assimilacionista, apesar de não demonstrar isso de forma declarada. De maneira que o autor conclui que as relações entre o estado canadense e os aborígenes não mudaram.

Para Hedican (1995), o processo de devolução de poder aos indígenas teve início em 1978, quando o governo convidou os aborígenes para formulação de propostas com objetivo de promover um reforma constitucional. Tais propostas resultaram na promulgação de emendas constitucionais no ano de 1982:

Em 1990 protestos indígenas levaram à violência do governo nos confrontos entre, por um lado os Mohawk, e por outro lado a polícia junto com o Exército, em Oka, no Quebec. Foi somente a partir de 1990 que as decisões do Supremo Tribunal do Canadá forneceram uma base jurídica para os direitos indígenas em relação à pesca e à autonomia (BAINES, p. 123).

${ }^{14}$ FOLHA DE SÃO PAULO, tiragem de 5 de setembro de 1993. Disponível em: <<

http://acervo.folha.uol.com.br/fsp/1993/09/05/5//4859774> Matéria: Canadá solucionou disputa, p. 3 e 4. 
No Brasil, as terras destinadas aos índios e as que eles permanecem são de propriedade da União, sendo resguardado aos índios apenas o direito ao usufruto e à exploração das riquezas naturais de tais terras, conforme artigos 22 e 32 do Estatuto do Índio. O artigo 17 do Estatuto, trata das terras chamadas dominiais, recebidas pelos índios em ações de direito, doações feitas por órgãos federais, compra e venda, ou áreas de reservas legais indígenas, ou ainda, apenas áreas ocupadas por índios que sejam de posse permanente. Tais terras independem de processo demarcatório, conforme artigo 198 da Constituição Federal (OLIVEIRA, 1998):

O direito dos índios é originário, ou seja, decorre de sua conexão sociocultural com os povos précolombianos que aqui habitavam. Tal direito não procede do reconhecimento pelo Estado (nem é anulado pelo reconhecimento), mas decorre do próprio fato da sobrevivência atual dos grupos humanos que se identificam por tradições ancestrais e que se consideram como etnicamente diferenciados de outros segmentos da sociedade nacional (OLIVEIRA, 1996, p. 45).

Para demarcar as terras indígenas, o governo teria de desembolsar milhões para indenizar os atuais proprietários das terras; o adia cada vez mais a demarcação e aumenta o conflito fundiário no país. No Brasil há uma imensa concentração fundiária, e ainda assim, como observa Oliveira (1998, p. 68), "mesmo abrangendo o Brasil como totalidade, a proporção das terras indígenas em face às áreas de latifúndio seria somente de $18 \%$ ".

Nos dois países, as demandas dos indígenas requerem o reconhecimento de direitos básicos, pois mesmo com tantas leis e dispositivos constitucionais, os povos indígenas ainda carecem de reconhecimento. $\mathrm{O}$ que falta em ambos são projetos que visem reconhecer esses povos como nações autônomas dentro do próprio estado, para que criem suas políticas e vivam conforme sua cultura. Contudo, os projetos de nada valem, sem uma conscientização da sociedade de que os índios merecem reconhecimento e direitos. A mudança, para ser efetiva, deve começar na consciência dos cidadãos não indígenas de que esses povos devem ser respeitados.

O caso Nunavut no Canadá pode ser citado como conquista dos movimentos surgidos a partir dos anos 70 e nos últimos anos. No Brasil o marco para o fortalecimento da política indigenista foi a Constituição de 1988, pois além de outras provisões, dá aos índios o reconhecimento de ingressar em juízo de forma autônoma, sem a intervenção da FUNAI, é o que traz o artigo 232 da Carta.

Tanto no Brasil como no Canadá, proliferam as organizações políticas prol indígenas. Um dos problemas que surgiram foi a fragmentação dessas organizações por pensamentos distintos. A separação leva à uma disputa entre essas organizações, e o que foi criado para fortalecer a causa indigenista, acaba por enfraquecê-la; como o caso dos índios Ticuna no Brasil.

\section{[...] as facções que atualmente surgiram com base nas duas organizações políticas (Ticuna) no Brasil, o Conselho Geral da Tribo Ticuna (CGTT) e a Federação das Organizações e dos Caciques e Comunidades Indígenas da Tribo Ticuna (FOCCITT) se estruturaram ideologicamente em torno da aceitação ou não aceitação da presença de antropólogos entre as comunidades (LÓPES- GARCÉS, C., 2000, p. 220).}

Quando comparado com o Canadá, o número de lideranças indígenas bem articuladas politicamente no Brasil ainda é pequeno. No Canadá, profissionais indígenas lutam pela garantia de terras, saúde, educação e uma maior participação política. Importante salientar o papel das organizações não-governamentais que, no Brasil, vem desempenhando apoio significativo juntos as lideranças indígenas (BAINES, p. 125).

Contudo, há diferentes tipos de ONGs no país, aquelas que efetivamente defendem os direitos indígenas e aquelas que defendem os interessem de grandes empresas e empreiteiras 
que atuam em terras indígenas. Algumas ONGs ainda representam, infelizmente, um passaporte para aqueles que desejam altos cargos junto ao governo (BAINES, p. 126). Nesse sentido, o autor:

A privatização do indigenismo cresce com a atuação cada vez maior das ONGs indigenistas e ambientais, fortalecendo as desigualdades internacionais e a oposição entre os países doadores e países receptores de programas indigenistas-ambientais, e dessa maneira isentando os estados nacionais da sua responsabilidade para com os povos nativos.

\section{A partir de 1921, a Organização} Internacional do Trabalho iniciou estudos sobre trabalhadores indígenas em diversos estados. Tais estudos começaram a ser feitos em virtude do elevado número de indígenas que representavam força de trabalho, de maneira que a OIT buscava melhorias nas condições de trabalho dos indígenas (KAYSER, p. 331).

A partir desses estudos, a Organização Internacional do Trabalho criou diversas convenções que se dedicam a problemáticas jurídico trabalhistas envolvendo indígenas. A convenção mais conhecida é a 169 que dispõe sobre povos indígenas e tribais em países independentes. A Convenção 169 é, na verdade, uma revisão da Convenção 107. Segundo Kayser, além de trazer alterações conceituais, como por exemplo, a substituição do termo "populações" por "povos indígenas", traz também a correção de suposições equivocada de que os povos indígenas teriam menor valor e por isso, seriam indesejados pela sociedade, para uma visão de respeito à esses povos e a suas culturas.

Portanto, os avanços nas políticas indigenistas nos dois países foram significativos. O reconhecimento de suas identidades e culturas,

\footnotetext{
${ }^{15}$ Let us decide what we want taught in our schools. Let us decide how to manage the salmon fishery and the caribou and the forests. Let us set up our own structure where we can help our people to stay out of prison, or can teach our young people that sniffing gasoline is not the answer, a
}

bem como o direito sobre as terras, mesmo que a passos curtos, vem sendo conquistado. As normas positivadas são aparentemente suficientes para suprir-lhes o necessário. Contudo, falta à sociedade acabar o ranço e o preconceito contra esses povos, pois só a letra da lei não mudará a realidade dos povos aborígenes canadenses e dos povos indígenas brasileiros.

\section{CONSIDERAÇÕES FINAIS}

\begin{abstract}
Deixe-nos decidir o que nós queremos ensinar nas nossas escolas. Deixe-nos decidir como administrar a pesca de salmão, as renas e as florestas. Deixe-nos construir nossa própria estrutura, na qual poderemos ajudar nosso povo a ficar fora da prisão, ou podemos ensinar aos nossos jovens que cheirar gasolina não é a resposta, uma estrutura de governo construída com nossas próprias tradições, onde nossos anciões serão trazidos de volta aos seus lugares de direito, como verdadeiros líderes e lhes dado o respeito que eles merecem (testemunho de Kirk Lethbridge de Labrador antes da Royal Commission on Aboriginals Peoples, Embaixada Canadense (PERRY, 2001, p. 124) (tradução livre) $)^{15}$.
\end{abstract}

É visível que a base ideológica das políticas dos dois países é a mesma: o Estado deve proteger os indígenas das mazelas da sociedade branca. Estranho é que o próprio Estado que apresenta para sociedade essa ideologia, é o mesmo que não se opõe a invasão e tomada dos territórios indígenas, ao desrespeito e ao descaso e a situação de miserabilidade em que muitos deles vivem.

Apesar das mudanças trazidas com as legislações canadense e brasileira dos últimos anos, a situação de desrespeito e expulsão dos povos indígenas de suas terras persiste. Para KAYSER (2010), o problema reside no conflito entre as necessidades existenciais dos povos indígenas e a expansão econômica da sociedade majoritária.

structure of government that's built on our own traditions, where elders are brought back into their rightful place as the real leaders and given the respect that they deserve. (Kirk Lethbridge of Labrador testifying before the Royal Commission on Aboriginals Peoples, 1992. Canadian Embassy 1993:13) (PERRY, 2001, p. 124). 
São poucos os líderes políticos que fazem menção a um governo baseado no reconhecimento da autonomia dos povos indígenas, na demarcação de seus territórios tradicionais e na proteção efetiva de suas culturas. A legislação é clara, mas para executá-la de maneira satisfatória, os governos teriam que dispor de dinheiro, e solucionar os problemas dos povos indígenas não parece ser prioridade de todos, tanto no Brasil quanto no Canadá.

A fim de assegurar a sobrevivência dos povos indígenas de acordo com seu modo de vida, culminando em uma paz jurídica ideal, são necessárias diversas medidas. Cabe destacar ainda, a importância de projetos que estimulem a autonomia, as proteções à cultura iniciem os processos demarcatórios e a abolição da ideia de tutela e integração dos povos indígenas, seria o início de uma nova realidade social para esses povos.

Os resultados do contato com os europeus foram o genocídio dos nativos; a tentativa de integrá-los à sociedade não-índia; a expulsão dos povos indígenas de seus territórios tradicionais, a tentativa de massacrar sua cultura através da religião e do sistema educacional europeu e o excessivo preconceito que persiste na sociedade.

Nos dois países, a política integracionista foi forte por um bom tempo. Porém quando os governos brasileiro e canadense notaram que os povos indígenas não abririam mão de suas culturas e modo de vida, criaram diversas políticas e legislações, visando à proteção dos índios.

Ocorre que, uma legislação criada por não indígenas e aplicada a eles também por não índios, dificilmente vai atender as necessidades desses povos. O pensamento da sociedade e do legislador é voltado para a cultura, organização social e pensamentos, de não indígenas. Sendo assim, como poderiam essas leis trazer aos índios uma proteção efetiva? Uma vez que, os aplicadores dessas leis o fazem visando o melhor interesse da sociedade majoritária, e não o da minoria indígena.

Os povos indígenas brasileiros e canadenses lutaram, e sua melhor arma foi a resistência. Resistir à integração foi uma forma encontrada para proteger suas culturas e perpetuação. Conclui-se que no tocante à ideia integracionista, a luta de certa forma deu certo, pois as culturas indígenas persistem, algumas inclusive como se não houvesse tido contato com os europeus.

Com relação aos territórios, o Royal Proclamation no Canadá proibia o esbulho dos territórios indígenas. No Brasil, conforme Estatuto do Índio e a Constituição Federal de 1988, as terras indígenas pertencem à União, e é dos povos indígenas a legitimidade para usufruir desses territórios. Na prática, o que se vê são os índios aldeados em espaços cada vez menores e privados de seus verdadeiros territórios. No Brasil, a disputa por terras divide opiniões. Uns acreditam que os povos indígenas devem ter seus territórios devolvidos, mas a maioria é contra, pois boa parte desse território é voltada para agropecuária, de forma que o governo teria que indenizar os fazendeiros para desapropriá-los. E dispor de verba pública para solucionar o impasse dos territórios tradicionais não foi prioridade de nenhum governo até hoje.

No Canadá maior reivindicação dos povos aborígenes é o reconhecimento à autonomia e a cultura. O Indian Act trouxe uma série de previsões acerca das terras, da cultura, organização social e política, dentre outras. Quando comparado com as legislações brasileiras, o ordenamento jurídico indigenista canadense aparenta ter mais previsões de proteção aos povos indígenas. Porém, a situação do Canadá é a mesma do Brasil: o preconceito da maioria da sociedade faz com que esses direitos não sejam efetivados plenamente.

Os povos indígenas carecem de reconhecimento. Se a legislação indigenista fosse seguida e respeitada por toda sociedade não 
indígena, talvez a realidade desses povos fosse diferente. Os aborígenes canadenses e indígenas brasileiros sentem fome, fome de reconhecimento, fome de respeito, fome de autonomia. Os Estados devem considerar esses povos como participantes ativos na formação de novas legislações. Criando novas leis feitas por indígenas para seus pares, para que talvez deem a esses povos uma maior segurança jurídica.

\section{REFERÊNCIAS}

ARAÚJO, Ana Valéria. Povos Indígenas e a Lei dos "brancos": o direito à diferença. Ministério da Educação. Secretaria de Educação Continuada, Alfabetização e Diversidade. Brasília, 2006.

ASCH, M. From Calder to Van der Peet: aboriginal rights and Canadian Law, 1973-96. In: HAVEMANN, P. (Ed.) Indigenous Peoples Rights in Australia, Canada, \& New Zealand. Auckland: Oxford University Press, 1999.

BAINES, Stephen G. Organizações Indígenas e Legislações Indígenistas no Brasil, na Austrália e no Canadá. Rio de Janeiro: Arquivos do Museu Nacional, volume 61, número 2, p. 115-128, abril/junho. 2003.

BARRETO, Helder Girão. Direitos Indígenas. Vetores Constitucionais. Editora Juruá. 1a edição, Curitiba: 2003.

BASTOS, Celso Ribeiro. Curso de Direito Contitucional. São Paulo: Editora Saraiva, 20ª edição, 1999.

COLAÇO, Thais Luzia. Incapacidade indígena: Tutela religiosa violação do direito guarani précolonial nas missões jesuíticas. Curitiba: Juruá, 1999.

FIDLER, D. Red power in Canada. Toronto: Vanguard Publications, 1970.

HEDICAN, E. J. Applied Anthropology in Canada: Understanding aboriginal issues. Toronto: University of Toronto Press, 1995.

JOHNSON, H. Two families: treaties and government. Saskatoon: Purich Pub, 2007.

KAYSER, Hartmut-Emanuel. Os direitos dos povos indígenas no Brasil. Desenvolvimento histórico e estágio atual. (tradução Maria da Glória Lacerda Rurack). Porto Alegre: Asssociação Nacional dos Procuradores da República - Fundação Procurador Pedro Jorge, 2010.

LÓPES-GARCÉS, C. Ticunas brasileros, colombianos y peruanos: etnicidad y nacionalidade em la región de fronteras del Alto Amazonas-Solimões. Brasília: 2000.

LOSADA, Vânia Maria Moreira. Índios no Brasil: marginalização social e exclusão historiográfica. Diálogos Latinoamericanos, num. 3, 2001, pp. 87-113. Aaehus Universitet, Dinamarca.

MARÉS, Carlos Frederico de Souza. O Renascer dos Povos Indígenas Para o Direito. São Paulo: 2001.

MARÉS, Carlos Frederico de Souza. O Direito Envergonhado - O Direito e os Índios no Brasil. Revista IIDH, volume 15, 1992. 
MCNEIL, Kent. The Constitucional Rights of the aboriginal peoples of Canada. Supreme Court Law Review, vol. 4.255, p. 255-265.

MOISES, Beatriz Perrone. O mito do bom francês: imagens positivas das relações entre colonizadores franceses e povos ameríndios do Brasil e do Canadá. Instituto de Estudos Avançados da USP, São Paulo, 1996. Disponível em: <www.iea.usp.br>.

MOREIRA, Vânia Maria Losada. Os índios e Império: história, direitos sociais e agenciamento indígena. Trabalho Apresentado no XXV Simpósio Nacional de História, Simpósio Temático 36: Os Índios na História, 13-17 de julho de 2009.

OLIVEIRA, Frederico Cesar Barbosa de. Historical landmarks, state policies and indigenous selfdetermination in Brazil and in Canada. Indigenous Policy Journal Vol. XXIV, No. 1 (Summer 2013). Department of Anthropology. University of Toronto. p. 1-16.

OLIVEIRA, João Pacheco de. Tendências recentes na política indigenista no Brasil, na Austrália e no Canadá. XX Encontro Anual da ANPOCS - GT15 Política Indigenista. Minas Gerais, 1996.

OLIVEIRA, João Pacheco de. Terras Indígenas, Economia de Mercado e Desenvolvimento Rural. Indigenismo e territorialização: poderes, rotinas e saberes coloniais no Brasil contemporâneo. Rio de Janeiro: Contra Capa, 1998. p. 43-68.

PERRY, Richard John. From time immemorial: indigenous peoples and state systems. University of Texas Press: Austin, 2001.

RICARDO, Beto. Quem fala pelos índios? (II), In: RICARDO, Carlos Alberto (org.) Povos Indígenas do Brasil: 1991-1995. São Paulo: Instituto Socioambiental. 1996.

SAWCHUK, J. Anthropology and Canadian native political organizations: past and future trends. In: DYCK, N., \& WALDRAM, J.B. (Eds.) Anthropology, Public Policy and Native Peoples in Canada. Montreal: McGill-Queen's University Press, 1993.

SCHOULS, Tim. The basic dilemma: Sovereignty or Assimilation. In: Bird, L., Land, L, \& Macadam, M (Eds.) Nation to nation: Aboriginal sovereignty and the future of Canada (p.12-26). Toronto \& Vancouver: Irwin Publishing, 2002.

SILVA, Carlos Eduardo Lins da., FOLHA DE SÃO PAULO, Matéria: Número de índios quadruplica nos EUA. Tiragem de 5 de setembro de 1993, páginas 3 e 4 . Disponível em $<$ http://acervo.folha.com.br/resultados/buscade_talhada/?all_words=INUIT\&commit.x=23\&commit. $\mathrm{y}=18 \&$ commit=Enviar\&date[day $]=\&$ date $[$ month $]=\&$ date $[$ year $]=\&$ final_date $=\& f s p=$ on \&group_id=0 \&initial_date $=\&$ page $=3 \&$ phrase $=\&$ theme_id $=0 \&$ utf $8=\% \mathrm{E} 2 \% 9 \mathrm{C} \% 93 \&$ without_words $=\&$ words $>$.

SLATERRY, Brian. The Organic Constitution: aboriginal peoples and the evolution of Canada. Osgoode Hall Law Journal. Vol. 32, nº 1. York University, Toronto, Canada, 1996.

SUTTON, Mark. Making Canadian Indian Policy. Boston: Pearson, 2011. 
WEAVER, S. Struggles of the Nation-State to define aboriginal ethnicity: Canada and Australia. Capítulo 10. In: GOLD, G.L. (Ed.) Minorities and Mother Country Imagery. St. John's: Memorial University of Newfoundland, 1984.

Recebido em: 11/12/2016

Aceito em: 31/08/2017 
